\title{
An Enlarged Pragmatist Inquiry Paradigm for Methodological Pluralism in Academic Design Research
}

\author{
Gavin Melles, \\ Faculty of Design, Swinburne University of Technology, Victoria, Australia
}

\begin{abstract}
As part of a process of academic legitimization, design has made claims to be epistemologically and methodologically distinct from the Arts and Sciences. Among the multiple propositions that have been made about this distinctiveness little has been said about the fundamentally pragmatic nature of design research and practice. Pragmatism in both instrumental and critical forms is a robust epistemological and methodological terrain for design research, which architecture and built environment disciplines have explored as a basis for their methodological pluralism. In the newer design disciplines of industrial, interior, and communication design, theory fashions and the market (e.g. human-centred design, interaction design, retail design) predominate, and the rich heritage and relevance of pragmatism is poorly understood. An expanded pragmatist inquiry paradigm, incorporating visual and material argumentation and the opportunity for engagement with critical pragmatism, offers a way beyond the current "conceits" of design. Such a theoretically and philosophically informed epistemology has particular relevance to the current debates about scholarship in design as it proposes a provisional metanarrative - pragmatism - as the broad epistemological and methodological base for methodological pluralism in design research and practice.
\end{abstract}

Keywords: pragmatism, academic design research, mixed methods, new disciplines

\section{INTRODUCTION}

As part of a general move to legitimize the recently academized design, the newer design disciplines have recently shown interest in objectifying theory building (e.g. Friedman, 2003; Love, 2002). This is a somewhat expected move from practice fields attempting to legitimize their academic status in higher education, angst apparent in some recent discussions (Roth, 1999; Buchanan, 2001; Durling, 2002; Newbury, 2002). For design research, this has produced a proliferation of theory fashions and concepts each emphasizing particular concerns of the interior, industrial, graphic, and multimedia design process while simultaneously claiming universality. Jonas (2001), for example, laments "the reactive adoption of stylish ideologies ('small theories'/'theory fashions') which focus on isolated aspects of the field" (p. 6-4), and which have littered the design literature, such as product semantics, eco-design, human-centred design, field-specific models of particular product, environmental, or human concerns in design. To some extent, this agitated proliferation of "small theories" has been a response to the shadow cast by the more established design disciplines.

Specific design fields, such as interior, industrial, and interaction design, are distributed in varied disciplinary and faculty groupings in higher education, including architecture, engineering and technology, and computer science. These allegiances bring with them affiliation to certain discourses and practices which trouble the potential for design as a discipline to transcend the particular conversations and models of their domestic location. Pragmatism as an inquiry paradigm transcends these affiliations and has a legacy in a range of design fields, such as architecture, the built environment, and urban design and planning. An understandable reluctance by the newer disciplines to domination by more established disciplines may have blinded the newer fields to the value of an inquiry paradigm, which could bring form to the search for disciplinary consensus.

This paper suggests that acknowledging the fundamental pragmatism of design research and practice and developing an enlarged neopragmatism incorporating the vocabularies of textual, material, and visual argumentation will provide a platform, which design scholarship can use to justify its mixed methodology, legitimize its disciplinary 
status, and move beyond theory fashions. While my proposition for neo-pragmatism may be interpreted as a metanarrative, postmodernity has taught us to question (Lyotard, 1984); assent to pragmatism's broad principles will prove, I suggest, a useful albeit provisional move beyond current theory fashions. It may also answer to the "professional conceit" of current moves to develop design theory beyond a broad recognition of the contested and contingent nature of problem solving in design (Coyne, 2005).

\section{THE PRAGMATIST LEGACY AND THE VOCABULARIES OF DESIGN}

In his critique of "metaphysical" disputes, James $(1907$, p. 45$)$ defined the pragmatic method as tracing the practical consequences of competing arguments. In so doing, James argued that many pointless disputes about questions of no concrete applied relevance to society, education, politics, etc., should be ignored. Taking a special interest in the role of art, technology and aesthetics, Dewey further developed the pragmatist position and its consequences for education and society as a whole. Dewey viewed both arts and sciences as capable of providing moral and social critique and educational enlightenment to individuals through the experience of engaged inquiry of the world (Dewey, 1954; Hildebrand, 2000; Freedman, 2003). Dewey's "productive pragmatism" stressed the methodological commonalities and logic of the Arts and Sciences, noting that "even thought the arts and the sciences utilize different tools and operate with different types of materials, they nevertheless exhibit common logical or inquirential strategies insofar as they bring problematic situations within their respective fields to a fruitful conclusion" (Hickman, 2002, p. 67). This levelling of the Arts/ Science dichotomy is developed, as I outline below, in Richard Rorty's reinvigorated Deweyan pragmatics.

Dewey and pragmatism's general approach to knowledge and practice was ultimately underpinned by his naturalistic (as opposed to cognitivist) epistemology of thinking. Essential to this naturalism is a focus on the situated nature of knowledge as produced in and through experience, an insight familiar to designers post-Schön (Dewey \& Dworkin, 1959; Dewey \& Bentley, 1960). As Holder (1995) notes, "A naturalistic account of thinking . .. commences with the assertion that thinking is a process situated inextricably in experience, in experience as a complex whole.... Such an inquiry into the experiential basis of thinking will reveal the essential role of noncognitive structures in thinking, especially the structures of imagination" (p. 181). Such an account of experience and thinking is thoroughly compatible with the designers concerns in the production and interpretation of designing. It is an account that resurfaces in Schön's (1991) account of reflection-in-action as typical of the logic of professional practice, including design.

This naturalistic approach also extended to a situated account of truth and facts. Dewey also took an antirealist stance to facts as always factsof-a-case, in which "What counts as the facts for a particular sequence of inquiry is determined in the course of that very sequence of inquiry" (Hickman, 2002 , p. 70). Dewey and pragmatism, in general, prefers an instrumental warranted assertability to a "timeless Truth". Thus, "pragmatism rejects the view that scientific theories offer true or false descriptions of the world (rather than provisional tools for its manipulation), denies distinctions between theory and observation and fact and value, and prefers (following Dewey) to speak of 'warranted assertability' rather than truth" (Carr, 2003, p. 202; Margolis, 2007). Thayer-Bacon (2003) points to the fallibilistic nature of such warrants, “Thus, we call 'knowledge' or 'truth' by 'warranted assertibility' what we can assert to the best of our abilities, based on our best efforts to consider all options and solve all doubts" (p. 426). Warranted assertability itself contributes to the human good that all social practice should privilege. In Dewey's terms, "The human good must be sought for as (1) a process of critical reflection that confronts problematic situations, (2) the analysis of facts and relationships, and (3) the consideration of rival hypotheses in order to arrive at consequences that have a warranted assertability ... [which] is the designation of a potentiality rather than an actuality" (Hoy, 1998, p. 52). Such a provisional account of truth and the facts sits uneasily with a historic preference in the sciences for timeless truth claims but nonetheless accords well with many domains of experience and practice.

This instrumental and "potential" view of facts and resolution of problematic situations looks beyond any particular methodological affiliation, such as empiricist and interpretive paradigms (Kuhn, 1996) which tend 
to provide alternative quantitative and qualitative responses to research problems. Until recently the social science "paradigm wars" emphasized a dualist affiliation to either qualitative or quantitative methods based on purportedly incommensurable ontological and epistemological differences (Guba, 1990; Hammersley, 1992). However, neither paradigm has a special purchase on "nature's vocabulary" and the "idea that explanation and understanding are opposed ways of doing social science is as misguided as the notion that microscopic and macroscopic descriptions of organisms are opposed ways of doing biology" (Rorty, 1982, p. 197). These affiliations ultimately became moral as interpretivists associated their qualitative methods with a turn against scientific quantitative instruments of domination and social engineering, resulting in "a confusing quasi-politicization of what was already a factitious 'methodological' issue" (Rorty, 1982, p. 204).

In addition to his ability to resist and deflate specious dichotomies in historically sedimented arguments (Rorty, 1979), Rorty builds on the Deweyan parallels between the Arts and Sciences to claim that different "vocabularies" of the two domains, in their particular disciplinary manifestations, offer complementary and relatively advantageous interpretations of value to private and public projects (Rorty, 1989). From this vantage point, Nabokov's unintentioned playful contribution to new author-narrative-protagonist relationships in Bend sinister (1960), Gehry's originally unarchitectural deployment of visual forms into architecture, Clifford Geertz's textualisation of culture and his exposure of the Balinese particular and exotic to public gaze, Steve Reich's minimalist response to atonal and harmony, may speak to us through their particular vocabularies and have some private or public "pay off “ for our own or society's objectives. To acknowledge pragmatism as design's natural epistemological base is to accept this relativity that vocabularies, theories, models, may "pay off", as James (1907) was wont to say.

Thus, pragmatism shows an agnosticism with respect to the arts and sciences' particular claims to Truth; an instrumental focus on the value of theories, methods and vocabularies; and a fallibilistic interpretation of the processes leading to warranted assertability in the solution of problematic situations provides a critical foundation for considering pragmatism's representation and employment in design disciplines. These fallibilistic and practical pragmatist principles provide a natural background to metaphors of design as theoretical tools (Blackwell, 2006), knowledge-in-action (Schön, 1991) and ill-structured problem-solving (Rittel \& Webber,
1973). A full account of design scholarship's fundamental pragmatism will acknowledge the value of these metaphors.

\section{A PRAGMATIC ACCOUNT OF DESIGN THINKING AND PRACTICE}

In design it appears that it is a "vulgar" discourse of pragmatism (Cherryholmes, 1988) that prevails over the intellectually robust and ideologically critical version described above. As Hickman (2002) notes, "straight-line instrumentalist" readings of pragmatism misrepresent the Deweyan perspective on the distinctive critical and social value of the Arts and Sciences. Invoking an instrumental "what works" logic, vulgar pragmatism extracts designing from social and ideological context. Theory fashions in design, such as human-centred, user-centred, collaborative design, interaction design, universalize particular aspects or perspectives on the design process while simultaneously removing designed objects and their production from material and symbolic contexts.

A similar decontextualization of design process occurs in "theoretical" propositions for design thinking that remove designing from its practice origins. Design is not alone in being distracted from its practice-based origins. The pressure in practice-oriented professions, such as management, teaching, and nursing, to do academic theory has displaced a focus on more relevant practiceoriented perspectives (Koontz, 1980; Adler, 1991; Hallett, 1997; Upton, 1999). A return to a practice-invested situated account of design is a natural consequence of pragmatism's problem-oriented epistemology.

Schön (1991), who built explicitly on Dewey's legacy (e.g. Schön, 1992), suggested that major (e.g. architecture) and minor (e.g. interior design) professions are characterized by a "situated" practice oriented knowledge-in-action (see Stivers \& Schmidt, 2000). In doing so, Schön continued the pragmatic tradition of problematizing the theorypractice dichotomy (Coyne, 2005, p. 7). In response to Simon's (1981) widely publicized position on design as an artificial science which created optimal solutions to design problems, Rittel and Weber's (1973) countered the assumption that design problems were well structured. Schön (1991) added that Simon's "techno-rationalist" approach assumed well-structured problems and the need for a design science to fill the methodological gap between theory and practice; Schön's exemplification of knowledge-inaction is close in many respects to 
Bourdieu's articulation of situated production of habitus in social and professional fields (Bourdieu, 1977).

Recent accounts of design thinking and practice have somewhat obscured Schön's pragmatist insight while opting to focus on other constraints in design practice. Lawson (1997), for example, focuses on the multiple constraints and interpretive processes that define the environment within which the designer works. Nelson and Stolterman (2003), meanwhile, see design inquiry and problemsolving being "emergent systems-thinking" with interpretation and measurement both important. Most recently, Cross (2006) describes design thinking as oriented to solution of ill-structured problems through a constructivist process. These different propositions tend to reflect the engineering or architectural orientations of authors and obscure the practice-oriented nature of design knowledge, as outlined in Schön.

Science-based and technical rationalist (Schön, 1991) approaches to design theory had their zenith in engineering-oriented design science approaches in the late twentieth century (e.g. Hubka \& Ernst Eder, 1987; Cross, 1994), and took some inspiration from Herbert Simon's (1981) proposal. Sargent (1994) observed that design science approaches modelled on other disciplines were neither possible nor characterized good design practice. Another approach has been to put caveats on the kind of "science" (read approach) specific to design. Building on Simon and Schön, Findeli (2001), for example, prefers to talk of an "involved" science where "the scientific inquiry and attitude are carried into (instead of applied to) the field of the project, so that the former are modified by the latter, and vice versa" (p. 10). In general, however, the continued use of the term science in conjunction with design may simply be contributing to an objectified and rationalist perspective that obscures design's applied and practice-oriented processes and aims.

Notwithstanding the proliferation of models of design thinking and "science", the essential insight that wicked or ill-structured problems characterize the essential design problem space has not been lost. Buchanan's (1992) Dewey-inspired proposition for design as a liberal art rests on the recognition that "there is a fundamental indeterminacy in all but the most trivial design problems" (pp. 1516). Resolution of wicked problems is a pragmatic resolution process and thus "is not thinking directed toward a technological 'quick fix' in hardware but toward new integrations of signs, things, actions, and environments that address the concrete needs and values of human beings in diverse circumstances" (p. 21).

\section{INSTRUMENTAL AND CRITICAL PRAGMATISM IN DESIGN DISCIPLINES}

The pragmatist legacy has been acknowledged in fields concerned with human and material design, particularly fields concerned with the human and built environment, such as architecture, urban planning, and organizational research. In design fields where creativity and the visual arts tradition plays a greater role pragmatism might seem alien to these "humanistic" concerns but in fact, properly understood, is entirely compatible with research, practice, and decision-making in these fields also. Cherryholmes (1988) has championed a Rortian version of critical pragmatism in the context of educational policy and practice, emphasizing the aesthetic nature of judgements since "they are based upon visions of what is beautiful, good and true instead of fixed, structured, moral and objective certainties" (op. cit. p. 2). Cherryholmes contrasts this "visionary" pragmatism with "conventional" pragmatism (Barone, 1992) that is unreflective, and functionally and socially reproductive (op. cit.). Such aesthetic visions are central to the imaginative projections of design.

In fields such as architecture and engineering where material constraints are ever present in proposed built forms pragmatism has tended to be associated with efficiency and measurement. Ramroth (2006) suggests that the historical development of pragmatism and architecture in North America were intertwined processes and provided the resources for the breadth of conventional and ideological responses to architectural pragmatism. Particular examples of pragmatist-inspired architecture, such as the work of James Gamble Rogers (Betsky \& De Long, 1994), show this intertwined narrative playing out between the two world wars. Recently, Spector (2004) has claimed he is hopeful that an architecture of social engagement may be inspired by architecture reconsidering the value of Dewey's pragmatics. 
Meanwhile, the resonance of Rittel and Weber's (1973) "ill-structured" proposition for urban planning and design has been extensive (e.g. Christensen, 1985). Urban planners were in a postrationalist mood (Alexander, 1984) and searching for a new paradigm. Although the pragmatism of urban design is sometimes referred to as one of capitalist expediency (Lang, 1994), the contingent decision- making processes for characteristically "ill-structured" design problems, particularly in Forester's (1993) work, has expanded the illstructured problem metaphor to include concerns with the social and ideological domains of design. Forester's proposals for a critical pragmatism build on Habermas's theory of communicative action as an open and ideologically neutral environment for resolving social and practical problems. Forester applauds the close analysis or micro-politics of practitioner work in planning while seeking to link this with an awareness of the broader social and political consequences of decisions made - the macro-environment - and its effect on interaction; studies linking up the micro- and macro-politics of designing in the newer disciplines remain to be written.

Savage (2005) has discussed how the urban design curriculum can be redesigned to equip graduates to face the current real-world challenges they face education for "practising life" - in a context where industry-academic-professional mode 2 knowledge contracts dominate higher education (Gibbons et al., 1994). She looks to pragmatism as the natural philosophical companion to a theory-practice "indivisibility" for the built environment disciplines: "it is the imaginative reflection on practice, and the persuasion and argument necessary to modify practice, which is of most interest to work-based learning since these capabilities allow practitioners to turn their experience of practice into new knowledge" (p. 6). Organizational research as design has also found a natural ally in pragmatism. Romme (2003), for example, locates pragmatic design perspectives on organizational research as an interstitial response to the relative limitations of both Humanities and Science based approaches to this field. Design develops, and draws on, design propositions that are tested in pragmatic experiments and this approach, says Romme, is ideal for organizational research.
Designers are not necessarily limited by conventional pragmatic constraints and can retain agency and authorship even under such conditions. Juras (2001), for example, shows in the context of housing design and reconstruction in Croatia that the conventional pragmatism and limited economics driving housing design and construction can still be exploited or subverted by architects to reflect cultural heritage. This example and others drawn from the general field of designerly disciplines has much to teach the newly academized design disciplines about the scope, meaning, and application of pragmatism to its projects. It also has particular relevance to justifying an increasing reliance on mixed-methods research in a broad range of applied fields.

\section{PRAGMATISM AND MIXED METHODS IN APPLIED DESIGN RESEARCH}

Characterizing the built environment as interdisciplinary, Amaratunga et al. (2002) examine the benefits of mixed approaches to built environment problems although make no reference to pragmatism. In fact, mixed methods is the natural outcome of a commitment to pragmatism as an epistemological and methodological base. In the current context of industry-academic-professional hybrid knowledge production multiple methods and inter-disciplinarity are common denominators of research projects in higher education and other institutions.

Mixed methods has been justly described recently as a research paradigm whose time has come (Johnson \& Onwuegbuzie, 2004). Howe (1988) was one of the first to challenge the incompatibility thesis prevalent in the social sciences that “combining quantitative and qualitative methods is a good thing and denies that such a wedding of methods is epistemologically incoherent" ( $p$. 10). Howe noted that the dualist empiricist and interpretivist paradigms ignored pragmatism's claims or rejected them as a simplistic "what works" instrumentalism. The natural associations between mixed methods and a problem-oriented pragmatism as an inquiry paradigm have also been seen as a way past unproductive paradigm "wars" and the incommensurability thesis (Morgan, 2007). 


\begin{tabular}{|c|c|c|c|c|}
\hline Paradigm & Positivism & Postpositivism & Pragmatism & Constructivism \\
\hline Methods & Quantitative & Primarily quantitative & $\begin{array}{l}\text { Quantitative } \\
\text { +qualitative }\end{array}$ & Qualitative \\
\hline Logic & Dedcutive & Primarily deductive & $\begin{array}{l}\text { Deductive } \\
\text { +inductive }\end{array}$ & Inductive \\
\hline Epoistemology & $\begin{array}{l}\text { Objective point of view: } \\
\text { Knower and known are } \\
\text { dualism }\end{array}$ & $\begin{array}{l}\text { Modified dualism Find- } \\
\text { ings probably objec- } \\
\text { tively 'true' }\end{array}$ & $\begin{array}{l}\text { Both objective and sub- } \\
\text { jective points of view }\end{array}$ & $\begin{array}{l}\text { Subjective point of view: } \\
\text { Knower and known are } \\
\text { inseparable }\end{array}$ \\
\hline Axiology & Inquiry is value-free & $\begin{array}{l}\text { Inquiry involves values } \\
\text { but may be controlled }\end{array}$ & $\begin{array}{l}\text { Values play a large role } \\
\text { in interpreting results }\end{array}$ & Inquiry is value-bound \\
\hline Ontology & Naive realism & $\begin{array}{l}\text { Critical or transcenden- } \\
\text { tal realism }\end{array}$ & Accept external reality & \\
\hline $\begin{array}{l}\text { Choose explanations } \\
\text { that best produce } \\
\text { desired outcomes }\end{array}$ & Relativism & & & \\
\hline Causality & $\begin{array}{l}\text { Real causes temporally } \\
\text { precedent to or simulta- } \\
\text { neous with effects }\end{array}$ & $\begin{array}{l}\text { There are some lawful, } \\
\text { reasonably stable rela- } \\
\text { tionships among social } \\
\text { phenomena which may } \\
\text { be known imperfectly } \\
\text { Causes are identifiable } \\
\text { in a probabilistic sense }\end{array}$ & $\begin{array}{l}\text { There may be causal } \\
\text { relationships but we } \\
\text { will never be able to pin } \\
\text { them down }\end{array}$ & $\begin{array}{l}\text { All entities simultane- } \\
\text { ously shaping each } \\
\text { other. It is impossible to } \\
\text { distinguish causes from } \\
\text { effects }\end{array}$ \\
\hline
\end{tabular}

Table 1.

Inquiry paradigms in Social Sciences

(Tashakkori \& Teddlie 1998, p.23)

Addressing the form, characteristics and value of mixed methods in social inquiry, Greene (2007) employs mental models to describe the individual qualitative or quantitative "lens" through which researchers view the task before them. Mental models or "cultural models" are to refer to socioculturally differentiated ways in which individuals as members of groups and communities talk about (and act out) aspects of the world, such as parenting, marriage, and relationships (Holland \& Quinn, 1987; D’Andrade \& Strauss, 1992; Shore, 1995). Eschewing debates about incommensurability, Greene (2007) proposes that through a practice of "active engagement with difference" (p. 14) mixed-methods studies then "invite multiple mental models into the same inquiry space for purposes of respectful conversation, dialogue, and learning one from another, toward a collective generation of better understanding of the phenomena being studied" (p. 13).

Methodological plurality and epistemological relativism - no Truth only situated truths - is a natural correlate of pragmatism, and "researchers may be both objective and subjective in epistemological orientation over the course of studying a research question" (Tashakkori \& Teddlie, 1998, p. 25). The authors offer a comparison of pragmatism with other prevalent paradigms in social and behavioural sciences (Table 1).

The practical possibilities for sequencing and combining qualitative and quantitative methods varies through a study and in line with the pragmatist focus on practical consequences no specific weighting or sequencing is claimed to be appropriate.

\section{AN EXPANDED PRAGMATIST INQUIRY PARADIGM FOR ACADEMIC DESIGN}

Notwithstanding the wealth of debate and exemplification of mixed methods in multiple disciplines, Cresswell and Plano Clark (2007) note the lack of discipline-based studies of mixedmethods research and the adaptations and variations of strategies in different disciplines. They propose that "Discipline-based reviews can thus classify and describe new design variants, including procedures specific to these models ... [and] can contribute to awareness and acceptance of mixed methods research within a discipline's unique context" (p. 191). The expanded pragmatist inquiry paradigm for design incorporating material and visual methods and strategies is the proposal here for disciplinary "uniqueness" (and absent from Table 1). This is not a new claim but rather an argument 
for mixed methods not as practical eclecticism but rather as methodological choice consistent with design's pragmatism. Groat and Wang (2002), for example, observe that mixed-methods research is often used for architectural projects involving human subjects although the rationale for method pluralism may simply be instrumental eclecticism.

\section{These two "vocabularies" of empiricism and} interpretivism lend stability and legitimacy to some academic disciplines. Design as a broad field could also claim some legitimacy and stability by adopting pragmatism as its methodological and disciplinary raison- d'être. However, an appropriate pragmatistinspired mixed methodology for design must expand beyond the qualitative-quantitative divide to include the material and visual elements of design fields. In visual arts inquiry, Sullivan (2005), for example, argues for "a more inclusive and holistic model" (Sullivan, 2005, p. 36) transcending the empiricist and interpretive divide and integrating material and visual languages.

Sullivan cites the example of the Californian architect Frank Gehry whose sketches and material concepting demonstrate the potential value of material arguments to scholarship. Gehry's concern with the links between furniture design and architectural form show that the smaller forum of newer design disciplines, such as industrial and product design, have significance only when seen in relational terms. Thus, “Gehry's furniture designs are a 'quick fix' of his architectural practice: their realization is relatively immediate and low cost, and they provide a satisfying smaller forum in which various design concerns, including ones relating to his buildings, may be explored" (http://www. guggenheim.org/exhibitions/past_exhibitions/ gehry/).

Buchanan (1992) suggests design practice has been characterized more by pluralism and pragmatism than theory, which has tended to neo-positivism. The pluralism and (conventional) pragmatism to which Buchanan refers is evident in the eclecticism of industry-based methods. Design research in consultancy and professional settings prefers an eclectic set of methods, e.g. focus groups, interviews, surveys, visual methods, framed by pithy justifications, which may be sufficient for undergraduates in professional programmes (e.g. Laurel, 2003). Discipline-specific areas of design, such as graphic design, allow for a more concerted focus on promoting particular methodological rationales (e.g. Noble \& Bestley, 2005). While such texts circulate as proposals for design research their manifest concern for industry relevance and their eclecticism suggests their obvious relevance to undergraduate professional training. However, lacking a methodological rationale such approaches will not suffice for design scholarship at the postgraduate research level (Friedman, 2003).

Recent discussions concerning the particular nature of design research have proposed multiple distinguishing characteristics and models for what this is while failing to acknowledge that the institutionalization and academization of design, similar to that of other applied disciplines, inevitably demands that distinctions be made. Even if we agree that following precedents in other major and minor applied professions, such as law, medicine, and nursing, that the main task of undergraduate education (and some postgraduate degrees) is preparation for professional practice a distinction has been and must be made in design regarding the objective of research-based scholarship in design.

While the conventional $\mathrm{PhD}$ was the only research route to design this distinction was easier to make than in the current environment where alternative doctorates in applied professional and creative fields have challenged this older tradition, and created different discourses of doctoral design (Durling, 2002). Professional doctorates focus attention on the workplace and advanced professional practice have been, for example, a natural institutional responses to a knowledge economy now focused on "useful" knowledge in higher education (Neumann, 2002; Usher, 2002; Tennant, 2004). Practice-based degrees in Art \& Design emphasize the material creative tradition of design with such doctorates representing a challenge to conventional $\mathrm{PhD}$ traditions, including in their insistence of the place of material outputs (Candlin, 2000; Winter et al., 2000; Hoddell et al., 2002; Dallow, 2003; Lester, 2004; Pedgley \& Wormald, 2007).

There is a growing tension in the design field about the relative rigour of some forms of research. Pragmatism looks beyond this to allow material, visual, and textual vocabularies as potential contributions to the instrumental and social 
projects of design. Thus, Coyne (2005) suggests that the theory-practice duality problematized by pragmatism can be recast in practice terms in design, "as a process of textural production, the drafting or formulaic responses, generating discursive interventions, creating verbal explanations, and hand drawing, model making, building furniture".

Conclusion: pragmatism, material thinking, and mixed methods in design Coyne (2005) suggests that taking pragmatism and postmodern scepticism seriously and attending to the lessons of Rittel and Weber and others may lead us to discover that apparent problems such as what is an adequate theory of design "may seem unproductive, irrelevant, or even quaint now" (p. 13). In line with this thinking, this paper suggests that at best design scholarship in particular may function well with a rather broad acknowledgement of its pragmatic nature, a pragmatism incorporating certain metaphors about the nature of design knowledge. This acknowledgement will give purpose to the mixed methods that design currently employs on an ad-hoc eclectic basis and encourage an ongoing commitment to "consequential" readings of design arguments for real-world concerns.

I have alluded to a number of design projects in the more established fields of design which could exemplify the critical pragmatism and methodological pluralism proposed in this paper. However, this paper is a call to action for the newer design disciplines to transcend their immediate and transitional concerns with aspects of the design process and engage with pragmatism's legacy. This particular transformation or move, I suggest, remains unexemplified in the field because it may require design fields to de-centre the design object that currently draws their attention away from the network of social, ideological, and historical dimensions that have brought the possibility of the object into the public gaze.

If we accept the contingency of design in a scholarly domain where text work and artefact coexist then a major contribution of the designed outcome will be to continue a discussion, not just to resolve a practical problem. This is because, "there can be no straightforward causal connection between design texts (theories) and design artefacts (buildings, products), except that certain problem settings provoke the continuation of discussion and inquiry more than others, in a particular intellectual context" (Coyne, 2005, p. 14).

The argument for an expanded pragmatist inquiry paradigm is the particular theoretical contribution of this study. Such a consensual platform will achieve several practical and symbolic objectives. Recognizing that different design disciplines and cultures have a variety of ways of representing the design process and employing material objects to achieve this (Henderson, 1998), the intention is not to create a totalizing discourse that excludes the particular. Rather this paper proposes to substitute a well-established and potentially open methodological vocabulary for the endless proliferation of local models such as user-centred, contextual design, etc., as the relevant basis for design scholarship.

Simultaneously, the adoption of an inquiry paradigm with strong purchase in a range of applied and social science fields, including health, teaching, management, etc., will provide design with a frame of reference and discourse which can articulate the conversations design is and will be bringing to inter-disciplinary projects in such fields. A shared commitment to a pragmatist inquiry paradigm and the value of mixed methods in the pursuit of the aesthetically and socially acceptable designed alternatives can only improve design's potential as a service field. In addition, acceptance that a continuum of positions along a conventional to critical pragmatism is possible in all fields provides additional "glue" cementing design inter-disciplinary relationships.

Methodological pluralism is a hallmark of pragmatism and a familiar ally of industry-based design research. At the level of industry practice and consultancy, it is an eclecticism motivated by conventional pragmatist instrumentalism. Academic design scholarship, which aims to mark out a distinctive space for itself in relation to everyday practice, could benefit from a robust inquiry paradigm able to incorporate the wicked nature of design solution- making and the contribution of material and visual representation to this. A foregrounding of pragmatism's claim to be the inquiry paradigm of choice for design and the foundation for a mixed-methods approach could contribute to greater consensus on the distinctiveness of design in a more substantive way than some current propositions. 


\section{REFERENCES}

Adler, S. (1991). The reflective practitioner and the curriculum of teacher education. Journal of Education for Teaching, $17(2), 139-150$.

Alexander, E. R. (1984). After rationality, what? A review of responses to paradigm breakdown. Journal of the American Planning Association, 50(1), 62-69.

Amaratunga, D., Baldry, D., Sarchar, M., \& Newton, R. (2002). Quantitative and qualitative research in the built environment: application of "mixed" research approach. Work Study, 51(1), 17-31.

Barone, T. (1992). On the demise of subjectivity in educational inquiry. Curriculum Inquiry, 22(1), 25-38.

Betsky, A., \& De Long, D. G. (1994). James Gamble Rogers and the architecture of pragmatism. New York/Cambridge, MA: Architectural History Foundation/MIT Press.

Blackwell, A. F. (2006). The reification of metaphor as a design tool. ACM Transactions on Computer-Human Interaction (TOCHI), 13(4), 490-530.

Bourdieu, P. (1977). Outline of a theory of practice. Cambridge: Cambridge University Press.

Buchanan, R. (1992). Wicked problems in design thinking. Design issues, 8(2), 5-21.

Buchanan, R. (2001). Design research and the new learning. Design issues, 17(4), 3-17.

Candlin, F. (2000). Practice-based doctorates. International Journal of Art \& Design Education, 19(1), 96-101.

Carr, D. (2003). Philosophy and the meaning of "education". Theory and Research in Education, 1(2), 195-212.

Cherryholmes, C. H. (1988). Power and criticism: Poststructural investigations in education. New York: Teachers College Press.

Chiasson, P. (2001). Peirce's pragmatism: The design for thinking. Amsterdam and Atlanta, GA: Rodopi.

Christensen, K. S. (1985). Coping with uncertainty in planning. Journal of the American Planning Association, 51(1), 63-73.

Coyne, R. (2005). Wicked problems revisited. Design Studies, $26(1), 5-17$.

Creswell, J. W. (2003). Research design: Qualitative, quantitative, and mixed method approaches (2nd ed). Thousand Oaks, CA: Sage.

Creswell, J. W., \& Plano Clark, V. L. (2007). Designing and conducting mixed methods research. Thousand Oaks, CA: Sage.

Cross, N. (1994). Engineering design methods: Strategies for product design (2nd ed). Chichester and New York: Wiley.

Cross, N. (2006). Designerly ways of knowing. London: Springer.

D'Andrade, R. G., \& Strauss, C. (1992). Human motives and cultural models. Cambridge and New York: Cambridge University Press.

Dallow, P. (2003). Representing creativeness: practice-based approaches to research in creative arts. Art, Design \& Communication in Higher Education, 2(1), 49-66.
Dewey, J. (1954). Art and education: A collection of essays (3rd rev. and enlarged ed). Merion, PA: Baines Foundation Press.

Dewey, J., \& Bentley, A. F. (1960). Knowing and the known. Boston, MA: Beacon Press.

Dewey, J., \& Dworkin, M. S. (1959). Dewey on education. New York: Teachers College, Columbia University.

Durling, D. (2002). Discourses on research and the PhD in Design. Quality Assurance in Education, 10(2), 79-85.

Findeli, A. (2001). Rethinking design education for the 21st century: Theoretical, methodological, and ethical discussion. Design Issues, 17(1), 5-17.

Forester, J. (1993). Critical theory, public policy, and planning practice: Toward a critical pragmatism. Albany: State University of New York Press.

Freedman, K. (2003). Teaching visual culture: Curriculum, aesthetics and the social life of art. New York/Reston, VA: Teachers College Press/National Art Education Association.

Friedman, K. (2003). Theory construction in design research: Criteria: approaches, and methods. Design Studies, 24, 507-522.

Gibbons, M., Limoges, C., \& Nowotny, H. (1994). The new production of knowledge: The dynamics of science and research in contemporary societies. London: Sage.

Greene, J. C. (2007). Mixed methods in social inquiry (1st ed). San Francisco, CA/Chichester: Jossey-Bass/John Wiley [distributor].

Groat, L., \& Wang, D. (2002). Architectural research methods. New York: Wiley.

Guba, E. G. (1990). The paradigm dialog. Newbury Park, CA: Sage Publications.

Hallett, C. E. (1997). Pragmatism and Project 2000: The relevance of Dewey's theory of experimentalism to nursing education. Journal of Advanced Nursing, 26(6), 1229-1234.

Hammersley, M. (1992). The paradigm wars: Reports from the front. British Journal of Sociology of Education, 13(1), 131-143.

Henderson, K. (1998). The role of material objects in the design process: A comparison of two design cultures and how they contend with automation. Science Technology Human Values, 23(2), 139-174.

Hickman, L. A. (2002). Philosophical tools for technological culture: Putting pragmatism to work. Bloomington: Indiana University Press.

Hildebrand, D. L. (2000). Putnam, pragmatism, and Dewey. Transactions of the Charles S. Peirce Society, 36(1), 109-132.

Hoddell, S., Street, D., \& Wildblood, H. (2002). Doctorates - converging or diverging patterns of provision. Quality Assurance in Education, 10(2), 61-70.

Holder, J. J. (1995). An epistemological foundation for thinking: A Deweyan approach. In J. W. Garrison (Ed.), The new scholarship on Dewey (pp. 7-24). Dordrecht and Boston: Kluwer Academic.

Holland, D. C., \& Quinn, N. (1987). Cultural models in language and thought. New York: Cambridge University Press. 
Howe, K. R. (1988). Against the quantitative qualitative incompatibility thesis or dogmas die hard. Educational Researcher, 17(8), 10-16.

Hoy, T. (1998). The political philosophy of John Dewey: Towards a constructive renewal. Westport, CT: Praeger.

Hubka, V., \& Ernst Eder, W. (1987). A scientific approach to engineering design. Design Studies, 8(3), 123-137.

James, W. (1907). Pragmatism: A new name for some old ways of thinking: Popular lectures on philosophy (1st ed). London and New York: Longmans, Green.

Johnson, R. B., \& Onwuegbuzie, A. J. (2004). Mixed methods research: A research paradigm whose time has come. Educational Researcher, 33(7), 14-26.

Jonas, W. (2001). A scenario for design. Design Issues, 17(2), 64-80.

Juras, I. (2001). From the universal to the regional and back. International Journal for Housing and Its Applications, 25(3), 181-192.

Koontz, H. (1980). The management theory jungle revisited. Academy of Management Review, 5(2), 175-187.

Kuhn, T. S. (1996). The structure of scientific revolutions (3rd ed). Chicago, IL: University of Chicago Press.

Lang, J. T. (1994). Urban design: The American experience. New York: Van Nostrand Reinhold.

Laurel, B. (2003). Design research: Methods and perspectives. Cambridge, MA: MIT Press.

Lawson, B. (1997). How designers think: The design process demystified (completely rev 3rd ed). Oxford and Boston: Architectural Press.

Lester, S. (2004). Conceptualizing the practitioner doctorate. Studies in Higher Education, 29(6), 757-770.

Love, T. (2000). Philosophy of design: A metatheoretical structure for design theory. Design Studies, 21(3), 293-313.

Love, T. (2002). Constructing a coherent crossdisciplinary body of theory about designing and designs: Some philosophical issues. Design Studies, 23(3), 345-361.

Lyotard, J. F. (1984). The postmodern condition: A report on knowledge. Minneapolis: University of Minnesota Press.

Margolis, J. (2007). Introduction: Pragmatism, retrospective, and prospective. In J. M. John R. Shook (Ed.), A companion to pragmatism (pp. 1-10). Oxford: Blackwell Publishing.

Morgan, D. L. (2007). Paradigms lost and pragmatism regained: Methodological implications of combining qualitative and quantitative methods. Journal of Mixed Methods Research, $1(1), 48-76$.

Nasokov, V. V. (1960). Bend sinister. London: Weidenfeld and Nicolson.

Nelson, H. G., \& Stolterman, E. (2003). The design way: Intentional change in an unpredictable world: Foundations and fundamentals of design competence. Englewood Cliffs, NJ: Educational Technology Publications.

Neumann, R. (2002). Diversity, doctoral education and policy. Higher Education Research and Development, 21(2), 167-178.
Newbury, D. (2002). Doctoral education in design, the process of research degree study, and the "trained researcher". Art, Design \& Communication in Higher Education, 1(3), 149-159.

Noble, I., \& Bestley, R. (2005). Visual research: An introduction to research methodologies in graphic design. Lausanne: AVA.

Pedgley, 0., \& Wormald, P. (2007). Integration of design projects within a PhD. Design Issues, 23(3), 70-85.

Ramroth, W. G. (2006). Pragmatism and modern architecture. Jefferson, NC: McFarland.

Rittel, H. W. J., \& Webber, M. M. (1973). Dilemmas in a general theory of planning. Policy Sciences, 4(2), 155-169.

Romme, A. G. L. (2003). Making a difference: Organization as design. Organization Science, 14(5), 558-573.

Rorty, R. (1979). Philosophy and the mirror of nature. Princeton, $\mathrm{NJ}$ : Princeton University Press.

Rorty, R. (1982). Consequences of pragmatism: Essays, 1972-1980. Minneapolis: University of Minnesota Press.

Rorty, R. (1989). Contingency, irony, and solidarity. Cambridge and New York: Cambridge University Press.

Roth, S. (1999). The state of design research. Design Issues, 15(2), 18-26.

Sargent, P. (1994). Design science or nonscience. Design Studies, 15(4), 389-402.

Savage, S. (2005). Urban design education: Learning for life in practice. Urban Design International, 10, 3-10.

Schön, D. A. (1991). The reflective practitioner: How professionals think in action. Aldershot: Avebury.

Schön, D. A. (1992). The theory of inquiry: Dewey's legacy to education. Curriculum Inquiry, 22(2), 119-139.

Shore, B. (1995). Culture in mind: Cognition, culture, and the problem of meaning. New York: Oxford University Press.

Simon, H. A. (1981). The sciences of the artificial(2nd ed). Cambridge, MA: MIT Press.

Spector, T. (2004). Pragmatism for Architects. Contemporary Pragmatism, 1(1), 133-149.

Stivers, C., \& Schmidt, M. R. (2000). You know more than you can say: In memory of Donald A. Schön (1930-1997). Public Administration Review, 60(3), 265-274.

Sullivan, G. (2005). Art practice as research: Inquiry in the visual arts. Thousand Oaks, CA: Sage Publications.

Tashakkori, A., \& Teddlie, C. (1998). Mixed methodology: Combining qualitative and quantitative approaches. Thousand Oaks, CA: Sage.

Tennant, M. (2004). Doctoring the knowledge worker. Studies in Continuing Education, 26(3), 431-441.

Thayer-Bacon, B. (2003). Pragmatism and feminism as qualified relativism. Studies in Philosophy and Education, 22(6), 417-438.

Upton, D. J. (1999). How can we achieve evidence-based practice if we have a theory practice gap in nursing today? Journal of Advanced Nursing, 29, 549-555.

Usher, R. (2002). A diversity of doctorates: Fitness for the knowledge economy? Higher Education Research \& Development, 21(2), 143-153. 
Winter, R., Griffiths, M., \& Green, K. (2000). The "academic" qualities of practice: What are the criteria for a practicebased PhD? Studies in Higher Education, 25(1), 25-37.

\section{CORRESPONDENCE}

Gavin Melles,

Faculty of Design,

Swinburne University of Technology,

Prahran Campus,

Victoria 3181, Australia.

E-mail: gmelles@swin.edu.au

Published online 28 November, 2008

ISSN 1749-3463 print/ ISSN 1749-3471

DOI: $10.1080 / 17493460802276786$

(C) 2008 Artifact 